\title{
BEHAVIORAL INTENTION OF YOUNG CONSUMERS TOWARDS E-WALLET ADOPTION: AN EMPIRICAL STUDY AMONG INDONESIAN USERS
}

\author{
Wijayanthi Isnawatie Mahwadha \\ Faculty of Economic and Business, University of Airlangga, Surabaya, East Java, Indonesia \\ E-mail: isna.wijaya10@gmail.com \\ ORCID: 0000-0002-0115-7443
}

\begin{abstract}
This research aims to find out what factors are influencing consumers use electronic wallet (e-wallet) as an alternative method of payment against the purchase of goods and services. Information for this research came from respondents who have made deals with the method of payment using the e-wallet in Surabaya, East Java, Indonesia. The respondents in this study are 183 respondents. The analysis methods in this study by using SEM with analysis tools using Smart PLS 3.2.7. This research obtained evidence that the hypothesis is accepted. Factors perceived usefulness perceived trust and capable of influencing attituted toward using that then give rise to behavioral intention to use e-wallet. Moderation variables in this reseach are full moderation due to the entire value of the indirect variables is greater than the value of direct variable. The limitations of this research is only done in Surabaya, East Java-Indonesia. So, this study could not be used to make generalizations about the behavior intention of Indonesian young consumers towards e- wallet. The results of this research can be used by consumers, the banking, mobile operators, as well as subsequent researchers to be able to improve the facilities of the service, improve the security of transactions, increased security of personal data as well as additional reference material in the decision-making process. This research was different to previous research, this study uses two variables, namely moderation attitude toward using moderate usefulness against perceived behavioral intention, as well as the perceived usefulness of variables to moderate the perceived trust against the attitude toward using.
\end{abstract}

\section{KEY WORDS}

Indonesia, e-wallet, structural equation modelling, behavioral intention, young consumers.

The development of increasingly advanced era like today, have an impact on the growth of technology, business and economy is growing rapidly. Rapid development of technology provides a very convenience to all human activity. One of the resulting ease with which the technological advancement that is the invention of the internet. According to the Federal Networking Council (1995) the internet is "the global information system that (1) is logically linked together by a a globally unique address space based on the Internet Protocol (IP) or its subsequent extensions/follow-ons, (2) is able to support communications using the Transmission Control Protocol/Internet Protocol (TCP/IP) suite or its subsequent extensions/follow-ons, and/or other IP-compatible protocols, and (3) provides, uses or makes accessible, either publicly or privately, high level services layered on the communications and related infrastructure described herein. " The Internet has 3 privileges, first privileges are giving freedom, the internet gives users the power to kind of give each other and receive information freely. Second, the internet is more dynamic as well as keeping track of the time. Most of the information in the usual internet accessible information is the most recent if compared to the information provided on printed media. The third is a privilege yang bersifat interactive network. Every penggunanua it is possible to be able to interact with other users in the world at any time (Kayo et al., 1996 in Aalydia, 2013).

Based on data released by the internetworldstats.com, until 31 March 2017 the number of internet users in the world is 2738949556 user or $36.43 \%$ of the whole population in the world (Figure 1). Indonesia finished fifth of internet users in the world, after China, India, the United States and Brazil. 


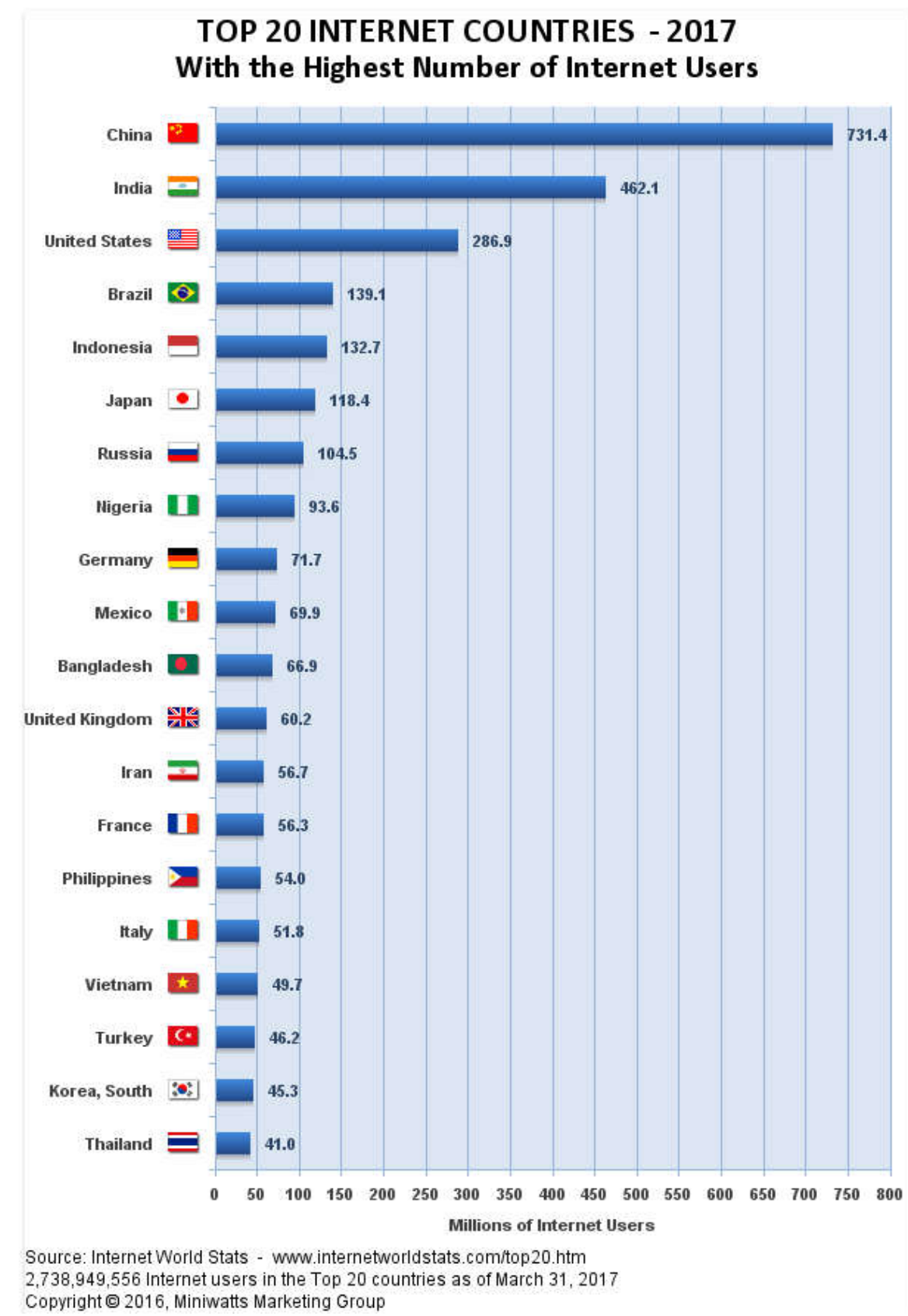

Figure 1 - Internet top 20 Countries with the Highest Number of Internet Users (Internet Stats Worlds, 2017)

Based on the results of a survey conducted by the Association of Indonesia Internet Service Provider (APJII) in 2016, from 132.7 million internet users or $51.5 \%$ of the total population of Indonesia as much as 256.2 million, $52.5 \%$ are male and $47.5 \%$ are female. From this survey, it is also know that $29.2 \%$ of internet users in indonesia are aged $35-44$ years, $24.4 \%$ of users aged $25-34$ years, $18.4 \%$ of users aged $10-24$ years, $18 \%$ user aged 45-54 year and the rest is user aged 55 years upwards (Figure 2). The majority of internet users in Indonesia (65\%) are in Java (Figure 3). While based on the type of device used, $50.7 \%$ or 67.2 million use smartphones and computers, $63.1 \%$ or 47.6 million people only use Smartphones and the rest is just using the computer (Figure 4). Based on research carried out digital eMarketeer Research Institute published by the Tempo, the number of active users of the smartphone in Indonesia in the year 2018 predicted capable of reaching 100 million people. With the number of Indonesia could be the fourth asian giant's digital technology after China, India and the Americas. 


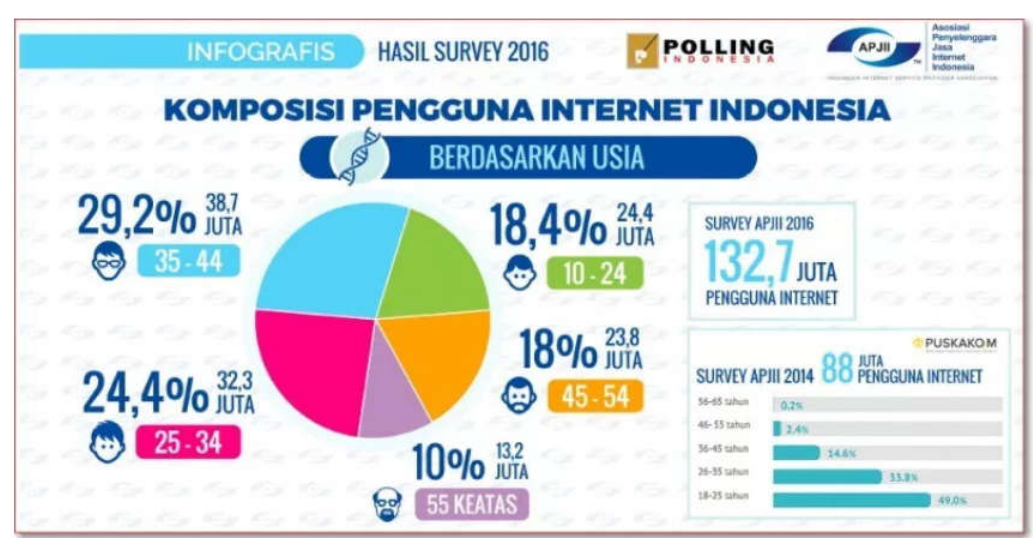

Figure 2 - Composition of Indonesian Internet Users (APJII, 2016)

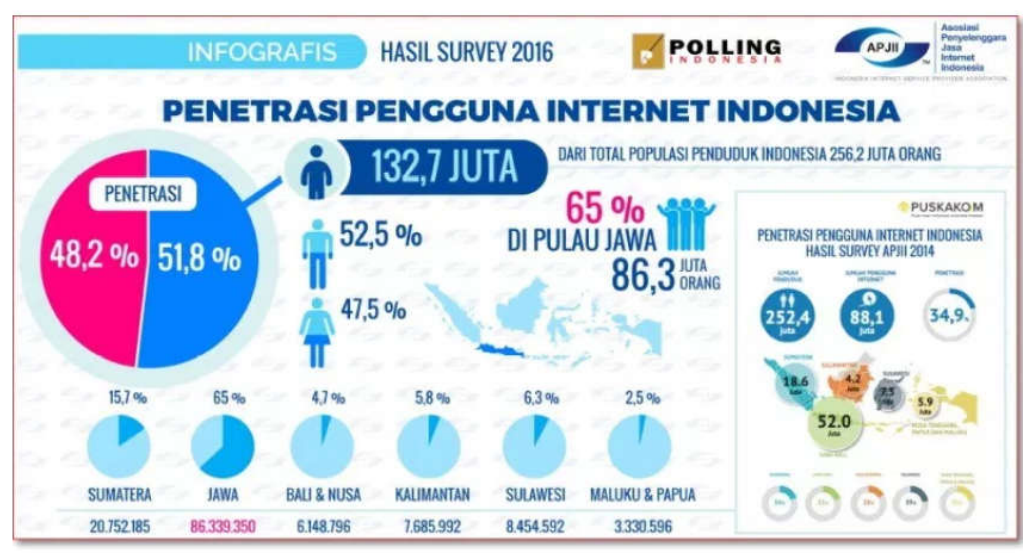

Figure 3 - Penetration of Indonesian Internet Users (APJII, 2016)

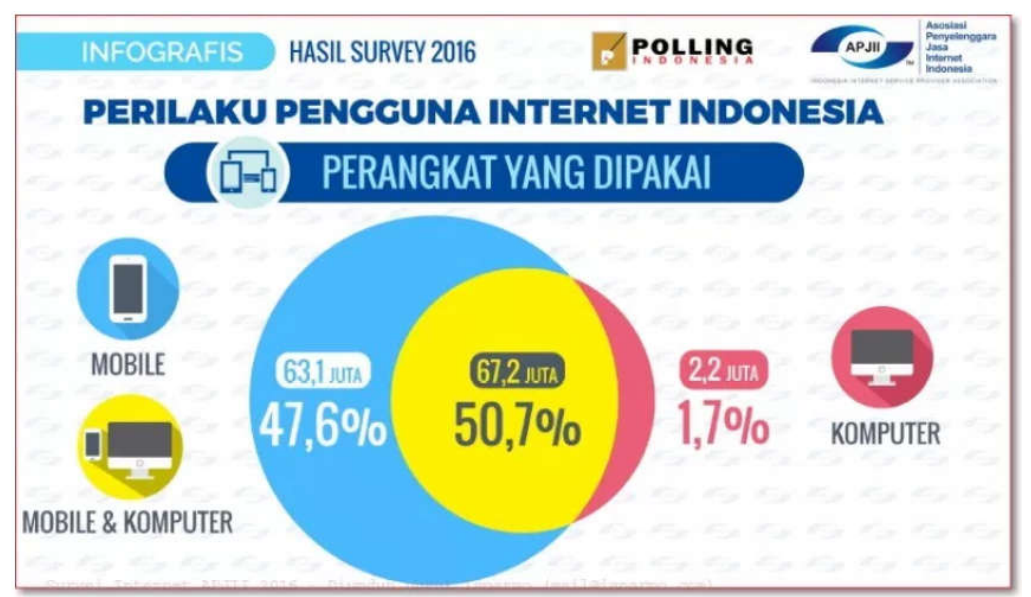

Figure 4 - Devices Used by Indonesian Internet Users (APJII, 2016)

With growing technology as well as a growing number of smartphone users, business also continues to innovate and collaborate in order to be able to answer the challenge of globalization, able to meet the needs of users as well as being able to provide the best service. One of the services provided, namely the application of the digital wallet (e-wallet). e-Wallet is an electronic money server based where in the process the usage needs to be connected first with sever publishers. In Indonesia there have been many types of digital wallets are available among other mobile phone Accounts, CIMB Niaga, my purse Indosat, Telkomsel, T-cash Finpay Finnet, Doku Wallet Nusa Core Arta, XL cash, Telkom is based, pomegranate Mynt, fuel Money gems, Go-Pay Gojek, PayPal, Starbuck's Card, etc. According to the data of the Bank Indonesia $(\mathrm{BI})$ the amount of electronic money transactions 
from year to year has increased. In 2015 the number of electronic money transactions in Indonesia are 535.57 million transactions or 5.28 trillion rupiah. In 2016 there were 683.13 million transactions or 7.06 trillion rupiah (up 33.7\%). Whereas in 2017, from January until August 2017 recorded already as much as 479.5 million transactions or 6.69 trillion rupiah. The high use of electronic money in Indonesia is in 2017, the existence of a national movement of non cash (GNNT) issued by Bank Indonesia that strengthened the Bank Indonesia regulation (PBI) number 16/8/PBI/2014 regarding electronic money (e-money ) as well as regulation of the Minister of public works and Housing (PERMEN PUPR) number 16/PRT/M/2017.

Independent Digital Reseach Institute, Jakpat conducted a survey to 1,515 respondents across Indonesia 20-50 years old. From 2,515 respondents, $44 \%$ of respondents said already had digital wallet service (e-wallet). From the entire e-wallet use $75 \%$ of the respondents chose to use e-wallet because it is more practical to use, more secure transactions, no need to carry too much cash and avoid a refund that is not returned. But the intensity of use of the user is still low, the majority of respondents use e-wallet between 1-3 times a month. Rathore (2016) says the factors that affect the use of the ewallet, namely the freedom to use online payments, ease of purchase, brand loyalty and usefulness of the digital wallet. Further Rathore (2016) says that the e-wallet can be used as an alternative online payment but the issue of safety and security of the funds that are in the e-wallet, internet connection will also need to be considered. In addition to the security of the funds stored in the e-wallet, security of personal data users should also note (Varsha and Thulasiram, 2016). Consumers who have a sense of worry about the security risks and against transactions when using the mobile payment services may inhibit the development of mobile payment industry. Thus Lu et al. (2011) concluded that the use of mobile payment is affected by the trust. Consumer confidence is the key to success in business in this industry. Xin et al. (2011) conducted a study to look at the influence of trust towards mobile payment. From this research it is known that mobile service providers, vendors and mobile payment mobile technology affects trust in mobile payment, perceived reputation on the mobile service provider as well as mobile payment of vendors in the mobile payment trust.

Davis (1989) says that the technology acceptance model (TAM) has two factors influence perceived usefulness and perceived i.e. ease of use. Perceived usefulness is the view that user by using the system are able to improve the performance of a user's activities (Davis et al., 1989). However, perceived usefulness has no influence on perceive ease of use (Davis, 1993) but have the most influence on intention to use a technology (Davis, 1989). Cheong et al. (2004) says that the perceived usefulness of having a positive influence against the attitude toward using.

Based on the facts and prior research, then researchers would like to examine how the behavior intention of the young consumer to use the e-wallet. This study aimed to find out the factors that affect the behavior intention of a young consumer to use the e-wallet.

\section{LITERATURE REVIEW}

e-Wallet is an electronic money server based where in the process of use it needs to be connected first with sever publishers. e-wallets are not the same as a credit card or debit card, transactions with e-wallet is not directly through a third party or intermediari (Amoroso and Watanabe, 2012). Committee on Payment and Settlement Systems of the Bank for International Settlement define e-wallet as a multi-purpose prepaid card that can be used repeatedly to be used in small retail or payment other than coins. e-wallet different from emoney, according to halomoney.com here are some differences between different e-wallet with e-money:

- e-money in Indonesia are generally chip based planted on card or other media (chip based), while the e-wallet is an e-money based server;

- e-money is generally used for everyday used such as transaction in toll roads, public transportation ticket payments, transaction in retail outlets and ticket purchase at entertainment venues, while the e-wallet is typically used for shopping online, 
shopping in the offline retail outlets, the purchase of a pulse telephone, electric token payment, BPJS bill, pay-TV bills, etc;

- the maximum of e-money balance is only 1 million, while the e-wallet balance maximum can be up to 10 million.

Olsen et al. (2011) argues that the development of e-wallet is not due to the facilities provided by the mobile wallet, but because of the number of mobile devices are increased. Nowadays almost everyone has a mobile device and mobile device cannot be separated from daily life. Because of the increasing use of the mobile device, the business finally innovate using the mobile device as an intermediary to use e-wallet. From this statement it can be concluded that the e-wallet is present not as a replacement for cash transactions, but rather as a complement to money in cash.

Technology Acceptance Model (TAM). Technology acceptance model (TAM) is a concept developed by Davis (1989). This concept offers a theory for Foundation learning and understanding user behavior in accepting and using an information system. In this concept it is said that a person will tend to use a system if the system is reasonably easy to use and provide benefits for the user. TAM concept is based on the theory of reasoned Action (TRA) developed by Ajzen and Fishbein (2011). This theory says that the person's behavior is influenced by intend to engage in certain actions. Ajzen and Fishbein (2011) says a person's intentions was influenced by two factors, namely the attitude of the individual against the results of the actions and opinions of the individual sosisal environment.

TAM has the aim to explain the factors that affect user behavior information technology towards the acceptance of the adoption of an information technology (Cakmak et al., 2011; Seeman and Gibson, 2009). The expansion of the concept of TAM is expected to provide the fundamental information about the factors that encourage a person in being (Rose and Fogarty, 2006; Lee et al., 2010). According to Venkatesh and Davis (2000) the attitude of an information system is influenced by two factors, namely perceived usefulness and perceived ease of use. Perceived usefulness in define as a level of individual belief that use of the technology will improve its performance. While the perceived ease of use is the level of confidence that the individual use of technology makes it easier to get the job done.

Perceived Usefuless. Wen et al. (2011) defined perceived usefulness as a consumer assessment of the benefits of product information needed and felt when shopping at a webbased store. Davis (1989) says that the perceived usefulness is very similar to performance expectations, namely a person's belief in improving job performance using a system. Venkatesh et al., (2003) defines performance expectations can be defined as the extent to which individuals believe that their performance will increase when using a particular system. The performance of a task will be increased if a system can innovate in a way gives more profit than the previous system (Moore and Benbasat, 1991). So from the statement, hypotheses can be purposed:

- $\mathrm{H}_{1}$ : Higher the perceived usefulness (PU), then higher behavioral intention (BI) to use e-wallet;

- $\mathrm{H}_{2}$ : Perceived usefulness (PU) affect attitude towards using (ATU) e-wallet.

Perceived trust. Trust is the Foundation of interpersonal. A transaction between two or more parties will occur when each side trusts each other. The trust has been considered as a catalyst in a variety of transactions between sellers and buyers so that customer satisfaction can be realized as expected (Yousafzai et al., 2003). As the development of research, many researchers observe regarding the extent to which consumers perceive e-wallet application as a provider of reliable, relating to security and privacy policies. Confidence is considered an important factor in determining the intention of adopting similar technology (Chong at al., 2012; Zhang et al., 2012; Chong, 2013a, 2013b). Dahlberg, et al. (2003), Shin (2009), Amoroso and Watanabe (2012), Xin et al. (2013), and Ho Pham (2014) argues that the trust factor can be used as a strong predictor for adopting e-wallet. Research conducted Gefen et al. (2003) showed that a positive effect against the trust's interest to use the (intention to use). From the statement, hypotheses can be purposed:

- $\mathrm{H}_{3}$ : Perceived trust (PT) affect consumer's perceived usefulness (PU) e-wallet; 
- $\mathrm{H}_{4}$ : Higher the level of perceived trust (PT), then higher behavioral intention (BI) to use e-wallet.

Attitude Towards Using. Davis (1989) explains that the attitude toward using conceptualised as a stance against the use of the system in the form of acceptance or rejection when a user is using the technology. attitude toward using and subjective norm represents the impact on behavioral intention. Pikkarainen et al. (2004) says that perceived usefuless and perceived ease of use affect your attitude toward using and interest using internet banking.

- $\mathrm{H}_{5}$ : Consumer attitude towards using (ATU) affect Behavioral Intention (BI) to use ewallet;

- $\mathrm{H}_{6}$ : Consumer attitude towards using (ATU) mediates the perceived usefulness against Behavioral Intention $(\mathrm{BI})$ using e-wallet.

Behavioral Intention (BI). Behavioral Intention (BI) is a measure or level of intensity of an individual's intention to take a specific actionn(Ajzen and Fishbein, 2011). Factors such as perceived expectancy, Effort Expectancy, Perceived risk, Social Influence, price, trust, and the like are used to measure behavioral intention towards the adoption of technology (Lee et al., 2004; Scgierz et al., 2010; A, et al., 2012; Amoroso and Watanabe, 2012,; Madan and Yadav, 2016).

Research model. This research aims to find out what factors are influencing consumers use electronic wallet (e-wallet) as an alternative method of payment against the purchase of goods and services. So the research framework can be described as follows:

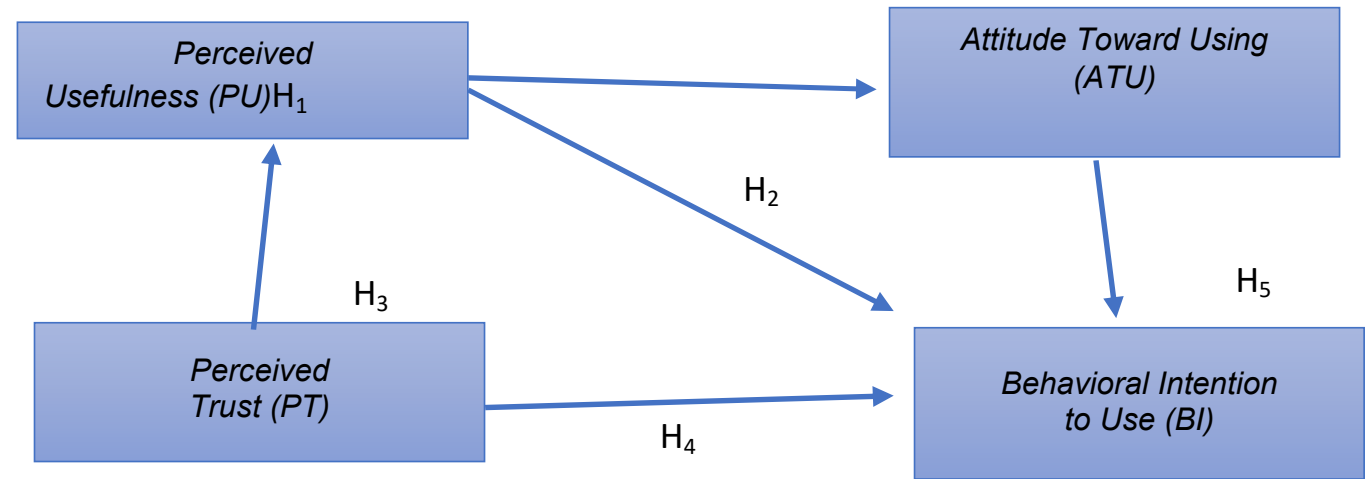

Figure 5 - Conceptual Model

\section{METHODS OF RESEARCH}

Participants. Information for this research came from respondents who have made deals with the method of payment using the e-wallet in Surabaya, East Java. Research using the prediction as done by Madan and Yadav (2016), that respondents have a mobile phone that can be used for internet and use e-wallet. Respoden the selected minimum 15 years old with at least high school education. The selection of respondents is intended so that respondents were able to understand questions and writings in the questionnaire so that it provides the right answers. In addition, young children are considered more responsive to technology and is the largest modern technology user segment (Davis, 1989; Hanafizadeh et al., 2014; Yadav, et al., 2016).

Construct measurement. This study uses four types of variables to be examined, i.e. independent variable, dependent variable, control variable and mediating variable. Independent variables comprising 2 variables, i.e. perceived usefulness (PU) and perceived trust (PT). Perceived usefulness, defined as usefulness which are perceived to improve the performance of user's information technology system and usefulness decision-making in the belief of perception (Davis, 1989). Measurement of perceived usefulness (PU) is done using a modified question 10 items from research conducted by Davis (1989), Dahlberg et al. (2003) and Venkatesh et al. (2012). The trust has been considered as a catalyst in a variety of transactions between sellers and buyers so that customer satisfaction can be realized as 
expected (Yousafzai et al., 2003). Measurement of perceived trust (PT) is done using a modified question 10 items from research conducted by Gofen et al. (2003), Hassanein and Head (2007), Wen et al. (2011) and Venkatesh et al. (2012).

The dependent variable in this study is behavioral intention $(\mathrm{BI})$. Research using four items used to measure the dependent variable (BI) modified from research Dahlberg et al. (2003). This research uses a variable mediation i.e. attitude toward using (ATU) as well as using the variable gender, education level, income, and employment as a control variable. The entire item is measured using a likert scale with ranges of 1-5. A value of 1 indicates the respondents strongly disagree with item asked and the value 5 indicates respondents strongly agree with item asked. The data collected was analyzed with the aid of further software SmartPLS Version 3.2.7. the selection of the software other than the software smartPLS SEM (like AMOS, LISREL, and EQS) due to component based PLS was able to avoid the two major problems faced by covariance based SEM that is inadmissible and factor indeterminacy (Tenenhaus et al., 2005).

The PLS analysis method was chosen by researchers based on several considerations. First, the PLS is an analysis method that does not require large samples, the number of samples less than 100 can already do the analysis. Second, the PLS may be used to analyze the theory still is said to be weak.

Research instrument. In this study, the method of collecting data obtained by disseminating a questionnaire. collecting data by questionnaire method is a technique of collecting data is done by giving a set of questions or written statement to the respondent (Sugiyono, 2015). Research instrument consisted of two parts. The first section contains information related to the profile of respondents consisting of age, gender, educational level and income of respondents. The second part contains information from respondents regarding the level of approval or disapproval against 29 items used to measure 4 variables. Before doing the study, first done pre-test by way of spreading the 30 questionnaires to respondents to know the reliability and validity of questionnaire that is used. If the data is already valid and reliable, will then disseminate the questionnaires back up to 185 respondents fulfilled.

The sampling technique in this study is a non-probability sampling techniques using convenient sampling and snowball. Convenient sampling method is one of unrestricted forms of non-probability sampling methods where the selection of the samples submitted to the researcher (Cooper and Schindler, 2006:139 and Malhotra, 2004). Another reason the use of this method that is a member of the sample shall be accessible because it can be found as well as implementation time relatively fast study as well as cheaper cost. According to Snedecor and Cochran (1967), when large populations are not knowable, then to determine the sample that is used can be calculated with the following formula:

$$
n=\left[Z^{2} \alpha \times \frac{(P \times Q)}{d^{2}}\right]=\left[1,96 \times \frac{\left(\frac{19}{30} \times \frac{11}{30}\right)}{0,05^{2}}\right]=182,062 \approx 183 \text { Questionnaires }
$$

Where: $\mathrm{n}$ - number of minimum samples; $Z^{2} \alpha$ - table $\mathrm{Z}$ which a level of significance that is expected; $\mathrm{P}$ - Proportion of the population is expected to have the characteristics as expected; $\mathrm{Q}$ - Expected proportion of the population does not have the characteristics as expected; D - Level of tolerable error (\%).

The sampling technique with the snowball technique was used in the initial test. As for the primary research survey used the technique of convenient sampling, dissemination through online questionnaires by google form and implemented during November 2017.

Data analysis. From the questionnaire while 65 accumulated, as many as 24 questionnaires cannot be used. So only 41 questionnaires can be used. The data collected is then performed the analysis using the assistance software SmartPLS 3.2.7. According to Chin (1998) an indicator can be said to have a high reliability if the indicator value greater than 0.70. As for indicators with a loading factor about $0.50-0.60$, it still can be done tolerance or can still be maintained, if the indicator is still in the development stage. So, at 
this time the research indicators which have to be issued from $<0.60$ model analysts. The results of the analysis on the first stage can be seen in Figure 6.

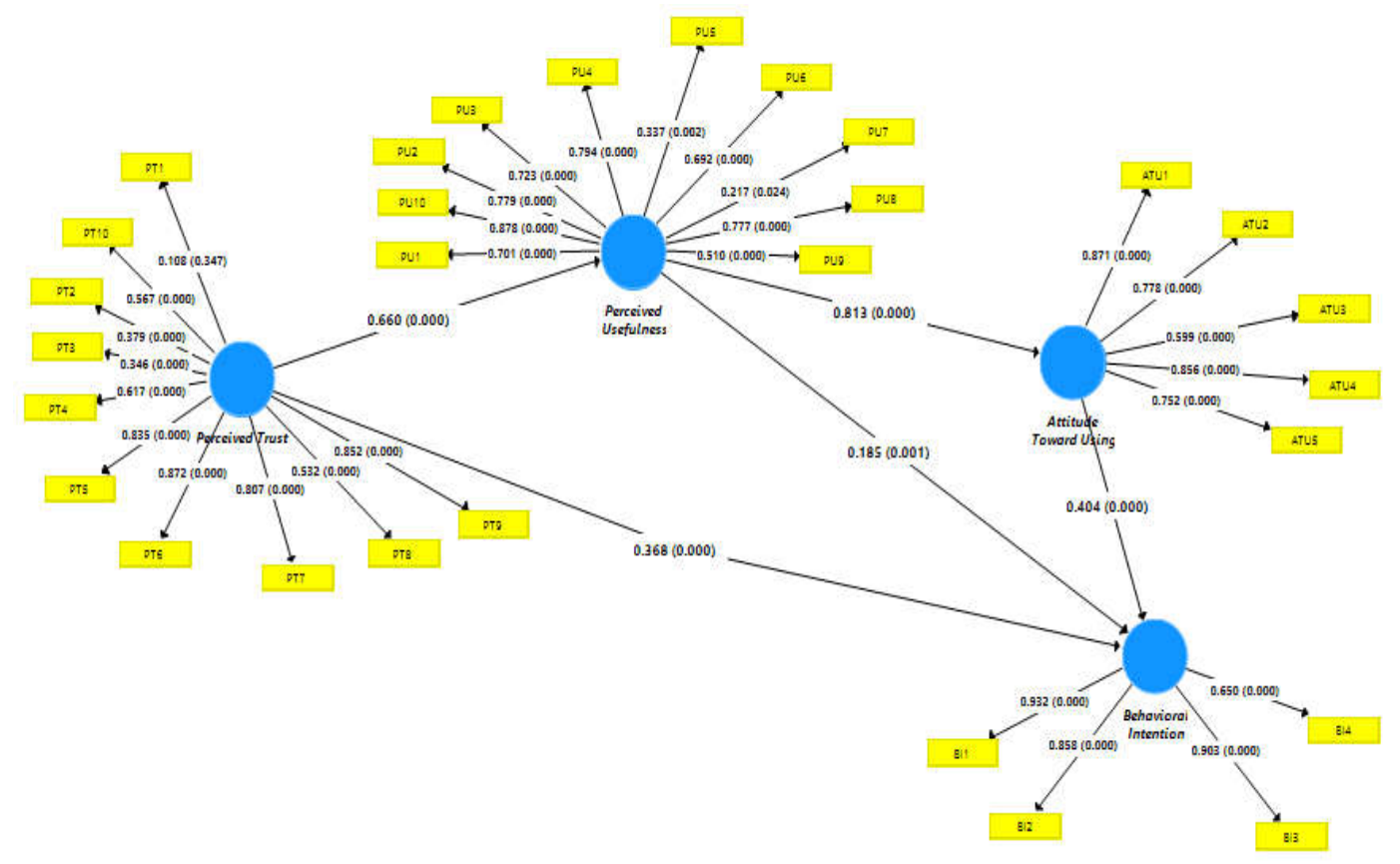

Figure 6 - Output Graph Model Step 1

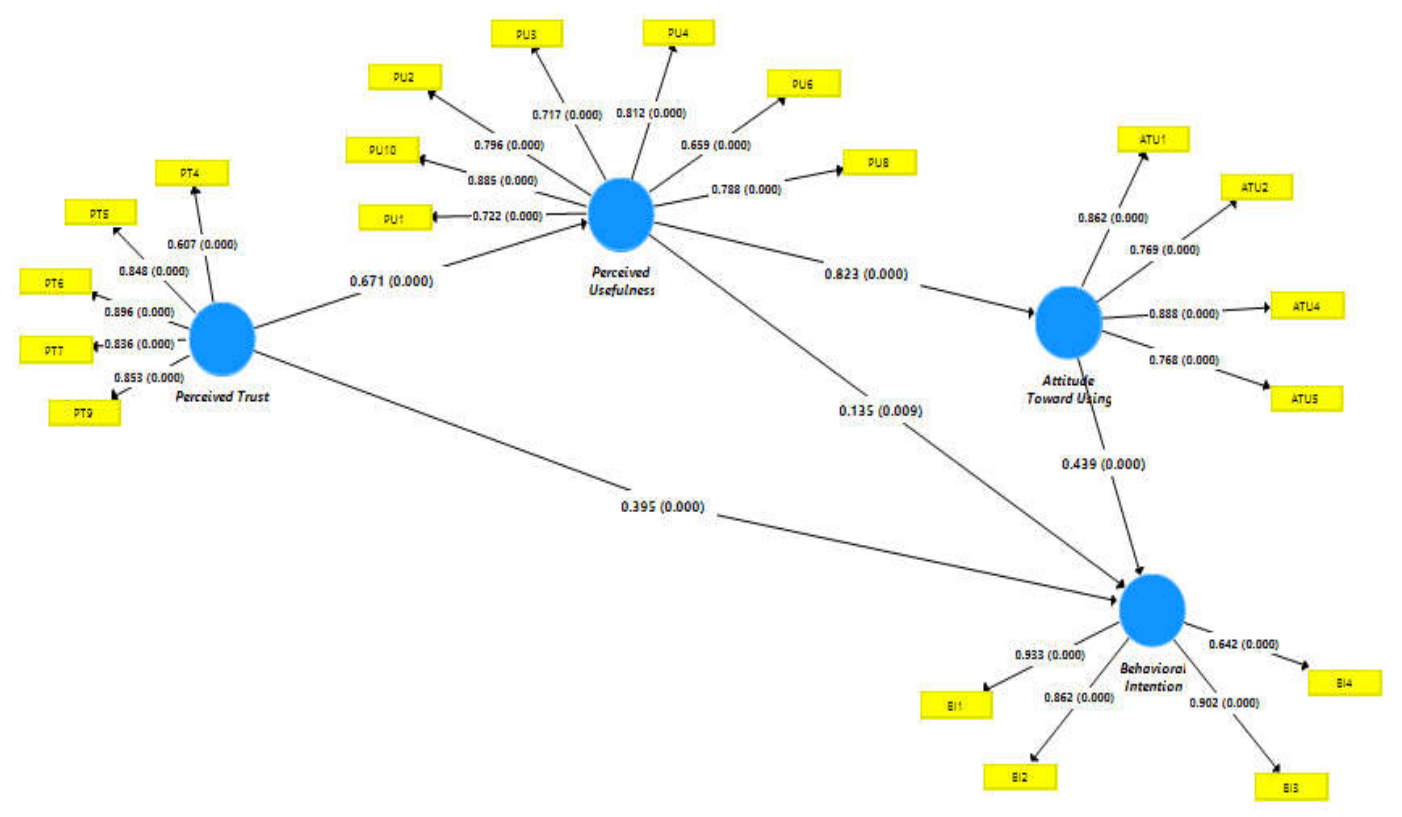

Figure 7 - Graph Model Output Step 2

First stage of the analysis, it can be seen that the indicator PT1, PT2, PT8, PT10, PT3, PU 5, PU7, PU9 and ATU3 should be excluded from the analysis because has a loading factor value less than 0.60 and insignificant (Figure 6). Next step is re-estimation on the model, following results from the second stage of PLS algorithm as seen on Figure 7.

From Figure 7, it can be seen that all the indicators used have been fulfilling the convergent validity because all indicators have the factor loading above 0.60 . Next to test discriminant validity is performed by comparing the square root of the average variance extracted $(\sqrt{ } \mathrm{AVE})$ for any invalid constructs with the correlation between invalid constructs 
with other invalid constructs in the model. The model has a discriminant validity enough if the root for each other invalid constructs AVE (Ghozali, 2014:63). A model is said good if each value of the AVE constructs are more than 0.50 (Ghozali, 2014:65). Discriminant validity in this study using Forwell Lacker Criterion.

Table 1 shows demographic profile of the respondents. The respondents in this study as much as 183 respondents. Based on the table above it can be seen that the majority of ewallet users in Indonesia are aged $15-25$ years $(74.86 \%)$ and aged $26-35$ years $(22.4) \%$ and most users are female $(75.96 \%)$. The education of the majority of the respondents are undergraduates, who is a student $(40.44 \%)$ and operational $(31.69 \%)$ with a majority income of IDR 1 million until IDR 4.99 million each month. Types of e-wallets are the most widely used in Indonesia is an e-money issued by Bank Mandiri. The average respondents using ewallet as much as 2-4 times in one month.

Table 1 - Demographic Analysis

\begin{tabular}{|c|c|c|c|}
\hline \multicolumn{2}{|c|}{ Sample Characteristic } & Frequency $(n=183)$ & $\%$ \\
\hline \multirow{4}{*}{ Age } & $15-25$ & 137 & $74.86 \%$ \\
\hline & $26-35$ & 42 & $22.40 \%$ \\
\hline & $36-45$ & 5 & $2.73 \%$ \\
\hline & $>45$ & - & - \\
\hline \multirow{2}{*}{ Gender } & Male & 44 & $24.04 \%$ \\
\hline & Female & 139 & $75.96 \%$ \\
\hline \multirow{5}{*}{ Education } & Senior High School & 12 & $6.56 \%$ \\
\hline & Diploma & 7 & $3.83 \%$ \\
\hline & Bachelor & 156 & $85.25 \%$ \\
\hline & Master & 6 & $3.28 \%$ \\
\hline & Doctor & 2 & $1.09 \%$ \\
\hline \multirow{4}{*}{ Income per month } & <IDR1 million & 36 & $18.58 \%$ \\
\hline & IDR1-2.99 million & 46 & $25.14 \%$ \\
\hline & IDR 3-4,99 million & 46 & $25.14 \%$ \\
\hline & > IDR 5 million & 58 & $31.15 \%$ \\
\hline \multirow{5}{*}{ Occuption } & Student & 74 & $40.44 \%$ \\
\hline & Operational & 58 & $31.69 \%$ \\
\hline & Managerial & 6 & $3.28 \%$ \\
\hline & Professional & 34 & $18.58 \%$ \\
\hline & Others & 11 & $6.01 \%$ \\
\hline \multirow{6}{*}{ Type of e-wallet } & e-money & 121 & $49.39 \%$ \\
\hline & T-cash & 78 & $31.84 \%$ \\
\hline & Mobile phone bill & 20 & $8.16 \%$ \\
\hline & Sakuku & - & - \\
\hline & Doku & 9 & $3.67 \%$ \\
\hline & Others & 17 & $6.94 \%$ \\
\hline \multirow{5}{*}{ Frequency } & $<2$ Times & 48 & $26.23 \%$ \\
\hline & 2-4 times & 72 & $39.34 \%$ \\
\hline & 5 - 7 Times & 22 & $12.02 \%$ \\
\hline & 8 - 10 Times & 3 & $1.64 \%$ \\
\hline & $>10$ Times & 38 & $20.77 \%$ \\
\hline
\end{tabular}

Source: Processed data (2017).

Table 2 shows output results of discriminant validity for each construct. The output of discriminant validity shows that all invalid constructs have a good value, because its value is greater than 0.50 . All constructs also do not contain multicollinearity, as seen in table 3 where all constructs have a VIF value under 5.

Besides testing construct validity and multicollinearity tests, also carried out testing the outer model. Testing the outer model using two criteria, called composite realibility and cronbach's alpha.

Results of cronbach alpha for variable attitude toward using, behavioral intention, perceived trust and perceived usefulness of $0.843 ; 0.858 ; 0.870$ and 0.886 . Whereas the value of variable reliability to commposite attitude toward using, behavioral intention, 
perceived trust and perceived usefulness of $0.894 ; 0.906 ; 0.906$ and 0.911 . All variables can be said to be reliable because it has a value greater than 0.70 .

Table 2 - Discriminant Validity

\section{Discriminant Validity}

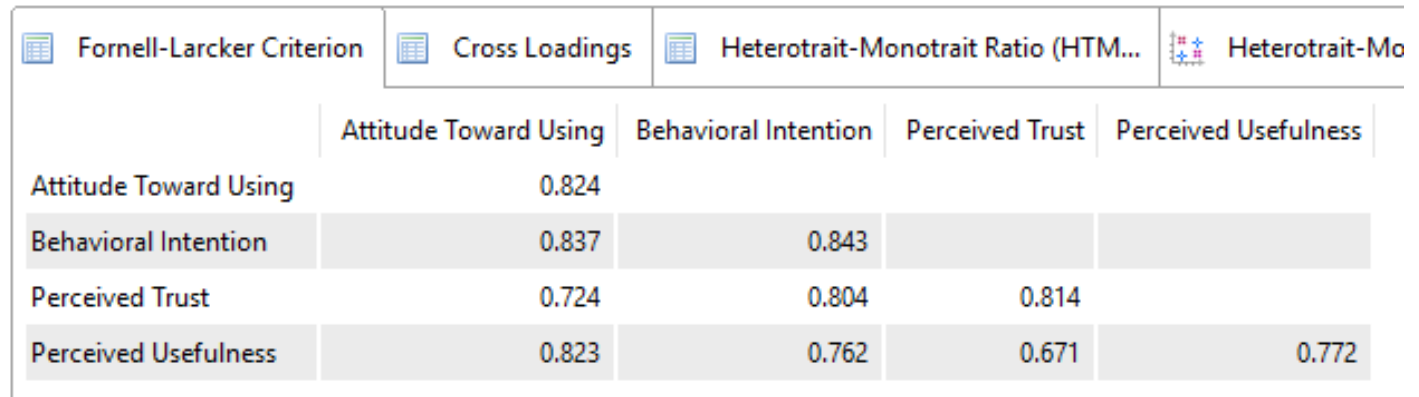

Table 3 - Test Multicolonierity

\section{Collinearity Statistics (VIF)}

\begin{tabular}{|c|c|c|c|}
\hline Outer VIF Values & 圆 Inner VIF Values & Outer VIF Values & Inner VIF Values \\
\hline & & & VIF \\
\hline & VIF & PT5 & 2.375 \\
\hline ATU1 & 3.082 & PT6 & 4.144 \\
\hline ATU2 & 2.249 & PT7 & 2.023 \\
\hline ATU4 & 2.849 & PT9 & 3.901 \\
\hline ATU5 & 1.994 & PU1 & 2.552 \\
\hline Bl1 & 4.326 & PU10 & 3.680 \\
\hline B12 & 2.946 & PU2 & 3.832 \\
\hline $\mathrm{B} \mid 3$ & 2916 & PU3 & 1.827 \\
\hline & 2.910 & PU4 & 2.347 \\
\hline BI4 & 1.422 & PU6 & 1.494 \\
\hline PT4 & 1.849 & PU8 & 2.222 \\
\hline
\end{tabular}

Table 4 - Composite Realibility and Cronbach Alpha

\section{Construct Reliability and Validity}

\begin{tabular}{|c|c|c|c|c|c|c|c|c|c|}
\hline \multirow[t]{2}{*}{ Matrix } & \multicolumn{2}{|c|}{ 新 Cronbach's Alpha } & 楛辛 rho_A & \multirow[t]{2}{*}{ 招整 } & \multicolumn{2}{|c|}{ Composite Reliability } & \multicolumn{3}{|c|}{ 拼直 Average Variance Extracted (AVE) } \\
\hline & & Cronbach & s Alpha & & rho_A & Composite $\mathrm{Re}$ & eliability & Average Variance Extracted $(t$ & (AVE) \\
\hline \multicolumn{2}{|c|}{ Attitude Toward Using } & & 0.843 & & 0.873 & & 0.894 & & .678 \\
\hline \multicolumn{2}{|c|}{ Behavioral Intention } & & 0.858 & & 0.891 & & 0.906 & & .710 \\
\hline \multicolumn{2}{|c|}{ Perceived Trust } & & 0.870 & & 0.892 & & 0.906 & & .663 \\
\hline \multicolumn{2}{|c|}{ Perceived Usefulness } & & 0.886 & & 0.901 & & 0.911 & & 0.595 \\
\hline
\end{tabular}

Structural model testing is done by looking at the value of $R^{2}$ which is a test of the model's goodnessfit (Ghozali, 2014:66). From the table above it can be seen that the value of 
$\mathrm{R}^{2}$ from the attitude toward using is 0.678 . This means the contribution of perceived usefulness against attitude toward using is $67.8 \%$. The contribution of perceived usefulness, perceived trust, attitude toward using against behavioral intention are $78.8 \%$. While the contribution of perceived trust against perceived usefulness is $45.1 \%$, and $54.9 \%$ explained by other variables.

Table 5 - Nilai $R^{2}$ and $R^{2}$ Adjusted

\section{R Square}

\begin{tabular}{|c|c|c|c|c|c|}
\hline \multirow[t]{2}{*}{ Matrix } & \multirow[t]{2}{*}{ 㩰算 R Square } & \multicolumn{3}{|c|}{ 㩰草 R Square Adjusted } & \\
\hline & & & R Square & R Squar & Adjusted \\
\hline \multicolumn{2}{|c|}{ Attitude Toward Using } & & 0.678 & & 0.676 \\
\hline \multicolumn{2}{|c|}{ Behavioral Intention } & & 0.788 & & 0.785 \\
\hline \multicolumn{2}{|c|}{ Perceived Usefulness } & & 0.451 & & 0.448 \\
\hline
\end{tabular}

Table 6 - F Square $\left(\mathrm{F}^{2}\right)$

f Square

\begin{tabular}{|c|c|c|c|c|c|}
\hline \multirow[t]{2}{*}{ Matrix } & \multicolumn{5}{|l|}{ 掉辛 f Square } \\
\hline & & Attitude Toward Using & Behavioral Intention & Perceived Trust & Perceived Usefulness \\
\hline \multicolumn{3}{|c|}{ Attitude Toward Using } & 0.245 & & \\
\hline \multicolumn{6}{|c|}{ Behavioral Intention } \\
\hline \multicolumn{3}{|c|}{ Perceived Trust } & 0.338 & & 0.820 \\
\hline \multicolumn{2}{|c|}{ Perceived Usefulness } & 2.106 & 0.027 & & \\
\hline
\end{tabular}

Path Coefficients

\begin{tabular}{|c|c|c|c|c|c|c|c|c|}
\hline \multirow[t]{2}{*}{ Mean, STDEV, T-Values, P-Values } & \multicolumn{2}{|c|}{ 囯 Confidence Intervals } & \multicolumn{3}{|c|}{ Confidence Intervals Bias Corrected } & Samples & \multicolumn{2}{|c|}{ Copy to Clipboard: } \\
\hline & & \multicolumn{2}{|c|}{ Original Sample (0) } & Sample Mean (M) & \multicolumn{2}{|c|}{ Standard Deviation (STDEV) } & T Statistics (|O/STDEV|) & P Values \\
\hline \multicolumn{2}{|c|}{ Attitude Toward Using -> Behavioral Intention } & & .439 & 0.433 & & 0.073 & 6.050 & 0.000 \\
\hline \multicolumn{2}{|l|}{ Perceived Trust -> Behavioral Intention } & & .395 & 0.400 & & 0.060 & 6.537 & 0.000 \\
\hline \multicolumn{2}{|l|}{ Perceived Trust -> Perceived Usefulness } & & .671 & 0.673 & & 0.045 & 15.041 & 0.000 \\
\hline \multicolumn{2}{|c|}{ Perceived Usefulness -> Attitude Toward Using } & & .823 & 0.826 & & 0.027 & 29.992 & 0.000 \\
\hline \multicolumn{2}{|c|}{ Perceived Usefulness -> Behavioral Intention } & & .135 & 0.133 & & 0.051 & 2.642 & 0.009 \\
\hline
\end{tabular}

Table 7

Path Coefficients

Testing $\mathrm{F}$ Square $\left(\mathrm{F}^{2}\right)$ is intended to measure the value of the effect size model. Effect size is said to be strong if the value of $F^{2}$ is larger than the value of $R^{2}$. The value of the effect size attitude toward using against behavioral intention is 0.245 . The value of the effect size of perceived trust against behavioral intention and perceived value each 0.338 and 0.820 . While the value of the effect size of perceived usefulness against attitude toward using and behavioral intention are 2.106 and 0.027 . Thus, it can be concluded that perceived 
usefulness has strong relationships with attitude toward using, because $\mathrm{F}^{2}$ value of perceived usefulness and attitude toward using greater than their $\mathrm{R}^{2}$ value.

The next test is meant to see the significance of the influence between the variable by looking at the value of the parameter and value the significance of coefficients t-stats. This test uses the Boostrapping Algorithm by using 500 subsample and significance level 0.05.

\section{DISCUSSION OF RESULTS}

From 230 questionnaires collected, only 183 questionnaire that can be used. While 47 cannot be used because respondents are not using e-wallet. The first stage of the analysis, it can be seen that the indicator PT1, PT2, PT8, PT10, PT3, PU 5, PU7, PU9 and ATU3 should be excluded from the analysis because the loading factor value is $<0.60$ and insignificant. Next, re-estimation on the model (see Figure 7). From the re-estimation results it is known that after several indicators have been issued, the overall indicators are left significant (PValue $<0.05)$. This means the entire indicators can be used as projection to measure each of the variables used.

Next will be a discussion of hypotheses based on the t-value of the modified structure model based on the results of the research that has been done:

$\mathrm{H}_{1}$ : Higher perceived usefulness (PU), then higher behavioral intention (BI) to use ewallet. Based on the results of the structural model testing conducted found that perceived usefulness (PU) has a positive and significant relationship against behavioral intention. This can be seen at the origin sample value is 0.135 and $t$-value is 2.642 ( $t$-value $>t$-table 1.96). So it can be said that $\mathrm{H}_{1}$ is accepted. The results of this research are consistent with the prior researchs by Amoroso and Watanabe, 2011; Davis, 1993; Lai, 2012, Shin and Kim, 2008 as well as the Madan and Yadav, 2016, they declare that there is a relationship between perceived usefulness and behavioral intention to use e-wallet.

$\mathrm{H}_{2:}$ Perceived usefulness (PU) affect attitude toward using (ATU) e-wallet. Based on the results of the structural model testing conducted found that the perceived usefulness having positive relationships and significantly to attitude toward using. This can be seen at the origin sample value is 0.823 and $t$-value is 29.992 ( $t$-value $>t$-table 1.96). So it can be said that $\mathrm{H}_{2}$ is accepted. The results of this research are consistent with prior researchs that says that Perceived usefulness (PU) affect attitude toward using (ATU) e-wallet (Amoroso and Watanabe, 2011; Davis, 1993; Lai, 2012, Shin and Kim, 2008).

$\mathrm{H}_{3:}$ Perceived trust (PT) affect consumer's perceived usefulness (PU) e-wallet. Based on the results of the structural model testing conducted found that perceived trust has a positive and significant relationship against perceived usefulness. This can be seen at the origin sample value is 0.671 and $t$-value is 15.041 (t-value $>\mathrm{t}$-table 1.96). So it can be said that $\mathrm{H}_{3}$ is accepted. The results of this research are consistent with the prior research by Lingyun and Dong (2008) who declare that perceived trust (PT) affect perceived usefulnes (PU).

$\mathrm{H}_{4}$ : the higher the level of perceived trust (PT), then higher behavioral intention (BI) to use e-wallet. Based on the results of the structural model testing conducted found that perceived trust has a positive and significant relationship against behavioral intention. This can be seen at the origin sample value is 0.395 and $t$-value is 6.537 ( $t$-value $>$ t-table 1.96). So it can be said that $\mathrm{H}_{4}$ is accepted. The results of this research are consistent with the prior research by Gefen et al. (2003) who said that perceived trust (PU) have positive effect against intention to use.

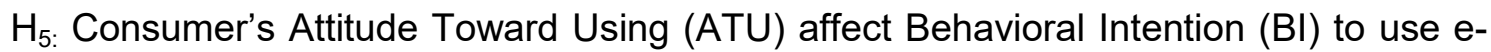
wallet. Based on the results of the structural model testing conducted found that the attitude toward using (ATU) has a positive and significant relationship against behavioral intention. This can be seen at the origin sample value is 0.439 and the $t$-value is 6.050 (t-value $>\mathrm{t}$ table 1.96). So it can be said that $\mathrm{H}_{5}$ is accepted. The results of this research are consistent with the prior researchs by Amoroso and Watanabe, 2011; Chau, 1996; Chen et al., 2002, Davis, 1993; Lai, 2012, Lu et al. 2005 and Shin, 2009 who said that there is relationship between attitude toward using (ATU) and behavioral intention (BI). 
$\mathrm{H}_{6:}$ Consumer's Attitude Toward Using (ATU) mediates perceived usefulness (PU) against Behavioral Intention $(\mathrm{BI})$ using e-wallet. Based on the results of the structural model testing conducted found that the attitude toward using (ATU) has a positive and significant relationship. This can be seen at the origin sample value is 0.361 . So it can be said that $\mathrm{H}_{6}$ is accepted. The results of this research are consistent with the prior researchs by Dahlberg et al. (2003) who said that attitude toward using (ATU) was able to mediate the perceived usefulness (PU) against Behavioral Intention (BI) using e-wallet.

\section{CONCLUSION}

From the explanation above, it can be seen that all hypotheses are accepted. The factors of perceived trust and perceived usefulness were able to influence attituted toward using which then led to the behavioral intention to use e-wallet. The moderating variable in this study is full moderation because all indirect variable values are greater than the direct variable value.

\section{LIMITATIONS}

The limitations of this research is only done in Surabaya, East Java-Indonesia. So, this study could not be used to make generalizations about the behavior intention of Indonesian young consumers towards e- wallet.

\section{REFERENCES}

1. Ajzen, Icek and Fishbein, Martin, 2011. Attitude and the Attitude-Behavior Relation: Reasoned and Automatic Processes, European Review of Social Psychology, Vol. 11 (1), Hal. 1-33.

2. Amoroso, Donald L. and Watanabe, Reny Magnier, 2012. Building a Research for Mobile Wallet Consumer Adaption: he Case of Mobile Suica in Japan, Journal of Theorical and Applied Electronic Commerce Research, Vol. 7 (1), Hal. 94-110.

3. Cakmak, Ahmet Ferda, Benk, Serkan and Budak, Tamer, 2011. The Acceptance of Tax Office Automation System (VEDOP) By Employees: Factorial Validation of Turkish Adapted Technology Acceptance Model (TAM), International Journal of Economics and Finance, Vol. 3 (6), Hal. 107-116.

4. Chin, W.W., 1998. PLS-Graph User's Guide Version 3.0, Soft Modeling Inc.

5. Cheong, J.H, Park, M.C. and Hwang, J.H., 2004. Mobile Payment Adoption in Korea: Switching from Credit Card, ITS $15^{\text {th }}$ Biennial Conference, Berlin, Germany, Hal. 4-7.

6. Chong, A.Y.L., Chan, F.T.S. and Ooi, K.B., 2012. Predicting consumer decisions to adopt mobile commerce: cross-country empirical examination between China and Malaysia, Decision Support System, Vol. 53 (1), Hal. 34-43.

7. Chong, A.Y.L., 2013. A two-staged SEM-neural network approach for understanding and predicting the determinants of $\mathrm{m}$-commerce adoption, Expert Systems with Applications, Vol. 40 (4), Hal. 1240-1247.

8. Chong, A.Y.L., 2013. Predicting m-commerce adoption determinants: a neural network approach, Expert Systems with Applications, Vol. 40 (2), Hal. 523-530.

9. Committee on Payment and Settlement Systems, 2003. A glossary of terms used in payments andsettlement systems. Bank for International Settlements. Tersedia di http://www.bis.org/publ/cpss00b.htm, diakses pada 23 November 2017.

10. Cooper, Donald R. and Schindler, Pamela S., 2006, Metode Riset Bisnis, Vol. 2, Edisi kesembilan.

11. Dahlberg, T., Mallat, N. and Öörni, A., 2003. Trust enhanced technology acceptance model

consumer acceptance of mobile payment solutions: tentative evidence, Stockholm Mobility Roundtable, Vol. 22, Hal. 23. 
12. Davis, Fred D., 1989. A Technology Acceptance for Empirically Testing New End-User Information Systems: Theory and Result, Doctoral Dissertation, Sloan School of Management, Massachusetts Institute of Technology.

13. Davis, Fred D., Bagozzi, Richard P. and Warshaw, Paul R., 1989. User Acceptance of Computer Technology: A Comparison of Two Theoretical Models, Management Science, Vol. 35 (8), Hal. 982-1003.

14. Davis, Fred D., 1993,. User Acceptance of Information Technology: System Characteristics, User Perceptions and Behavioral Impacts, International Journal of ManMachine Studies, Vol. 38 (3), Hal. 475-487.

15. Ghozali, Imam, Prof. H., M.com, CA., PhD., 2014. Structural Equation Model Metode Alternatif Dengan Partial Least Squares (PLS), Semarang: Universitas Diponegoro.

16. Gofen, D., Karahanna, E. and Straub, Detmar W., 2003. Trust and TAM in Online Shopping: An Integrated Model, MIS Quarterly, Vol. 27 (1), Hal. 51-90.

17. Hanafzadeh, A., Behboudi, M., Koshksaray, A.A. and Tabar, M.J.S., 2014. Mobilebanking

adoption by Iranian bank clients, Telematics and Informatics, Vol. 31(1), Hal. 62-78.

18. Hassanein, K. and Head, M., 2007. Manipulating Perceived Social Presence Through the Web Interface and Its Impact on Attitude Towards Online Shopping, International Journal of Human-Computer Studies, Vol. 65 (8), Hal. 689-708.

19. Lee, C.P., Warkentin, M. and Choi, H., 2004. The role of technological and social factors on the adoption of mobile payment technologies, AMCIS 2004 Proceedings, New York, Hal. 333.

20. Lee, Yu-Cheng, Li, Mei-Lan, Yen, Tieh-Min and Huang, Ting-Ho, 2010. Analysis of Adopting an Integrated Decision Making Trial and Evaluation Laboratory on a Technology Acceptance Model, Expert Systems with Applications, Vol. 37(2), Hal. 1745-1754.

21. Lu, Y., Yang, S., Chau, P.Y, and Cao, Y., 2011. Dynamic between the Trust Transfer Process and Intention to Use Mobile Payment Services: A Cross-environment Perspective, Information and Management, Vol. 48 (8), Hal. 393-403.

22. Madan, Khushbu and Yadav, Rajan, 2016. Behavioural Intention to Adopt Mobile Wallet: A Developing Country Perspective, Journal of Indian Business Research, Vol. 8 (3), Hal. 227-244.

23. Malhotra, 2004, Marketing Research, $5^{\text {th }}$ Edition, Pearson Prentice Hall.

24. Moore, Gary C. and Benbasat, Izak, 1991. Development of an Instrument to Measure the Perceptions of Adopting an Information Technology Innovation, Information Systems Research, Vol. 2 (3), Hal. 192-222.

25. Olsen, M., Hedman, J. and Vatrapu, R., 2011. e-wallet Properties, $10^{\text {th }}$ International Conference on Mobile Business, Como, Itali.

26. Pham, T.T.T. and Ho, J.C., 2014. What are the core drivers in consumer adoption of NFC-based mobile payments?: a proposed research framework, Management of Engineering \& Technology (PICMET), 2014 Portland International Conference, Kanazawa, Hal. 3041-3049.

27. Pikkarainen, T., 2004. $\mathrm{Ci}=$ onsumer Acceptance of Online Banking: An Extension of the Technology Acceptance Model, Internet Research, Vol. 14, Hal. 224-235.

28. Rathore, Hem Shweta, Dr., 2016. Adoption of Digital Wallet by Consumers, Journal of Management Research, Vol. 8 (1), Hal. 69-75.

29. Rose, J and Fogarty, Gerald J., 2006. Determinants of Perceived Usefulness and Perceived Ease of Use in the Technology Acceptance Model: Senior Consumers' Adoption of Self-service Banking Technologies, $2^{\text {nd }}$ Biennial Conference of the Academy of World Business, Marketing and Management Development: Business Across Borders in the $21^{\text {st }}$ Century, Paris, France.

30. Schierz, P.G., Schilke, O. and Wirtz, B.W., 2010. Understanding consumer acceptance of mobile payment services: an empirical analysis, Electronic Commerce Research and Applications, Vol. 9 (3), Hal. 209-216. 
31. Seeman, Elaine and Gibson, Shanan, 2009. Predicting Acceptance of Electronic Medical Records: is the Technology Acceptance Model Enough?, S.A.M. Advanced Management Journal, Vol. 74 (4), Hal. 21-26.

32. Shin, D.H., 2009. Towards an understanding of the consumer acceptance of mobile wallet, Computers in Human Behavior, Vol. 25(6), Hal. 1343-1354.

33. Snedecor, G.W. and Cochran, W.G., 1967, Statistical Methods, The lowa State Univversity Press, Ames, lowa.

34. Sugiyono, 2015. Metode Penelitian Bisnis, Edisi 15, Bandung: CV. Alfabeta.

35. Sultoni, Ahmad, 2013. Pengaruh Pemanfaatan Internet Sebagai Sumber Belajar Sejarah Terhadap Motivasi Belajar Siswa Kelas Xi Ips Sma N 1 Wiradesa Kabupaten Pekalongan Tahun Pelajaran 2011/2012, Skripsi, Universitas Negeri Semarang.

36. Tenenhaus, Michel, Vinzi, Vicenzo Esposito, Chatelin, Yves-Marie and Lauro, Carlo, 2005. PLS Path Modeling, Computational Statistic \& Data Analysis, Vol. 48 (1), Hal.159205.

37. Varsha R. and Thulasiram, M., 2016. Acceptance of e-Wallet Services: a Study of Consumer Behavior, International Journal of Innovative Research in Management Studies, Vol. 1 (4), Hal. 133-141.

38. Venkatesh, V. and Davis, F.D., 2000. A Theoretical Extension of the Technology Acceptance Model: Four Longitudinal Field Studies, Management Science, Vol. 46 (2), Hal. 186-204.

39. Venkatesh, V., Morris, M.G., Dvais, G.B. and Davis, F.D., 2003. User Acceptance of Information Technology: Toward a Unified View, MIS Quarterly, Vol. 27 (3), Hal. 425-478.

40. Venkatesh, Viswanath, Thong, James Y.L. and Xu, Xin, 2012. Consumer Acceptance and Use of Information Technology: Extending the Unified Theory of Accapetance and Use of Technology, Fortcoming in MIS Quarterly, Vol. 36 (1), Hal. 157-178.

41. Wen, C., Prybutok, V.R., and Xu, C., 2011. An Integreated Model for Customer Online Repurchase Intention, Journal of Computer Information Systems, Vol. 52 (1), Hal. 14-23.

42. Xin, H., Techatassanasoontorn, A.A., and Tan, F.B., 2013. Exploring the Influence of Trust on Mobile Payment Adoption, Jeju Island, South Korea: 2013 Pacific Asia Conference on Information Systems.

43. Yadav, R., Sharma, S.K. and Tarhini, A., 2016. A multi-analytical approach to understand and

predict the mobile commerce adoption, Journal of Enterprise Information Management, Vol. 29 (2), Hal. 222-237.

44. Yang, S., Lu, Y., Gupta, S., Cao, Y. and Zhang, R., 2012. Mobile payment services adoption across time: an empirical study of the effects of behavioural beliefs, social influences, and personal traits, Computers in Human Behaviour, Vol. 28 (1), Hal. 129142.

45. Yousafzai, S.Y., Pallister, J.G. and Foxall. G.R., 2003. A Proposal Model of e-Trust for Electronic Banking, Technovation, Vol. 23 (11), Hal. 847-860.

46. Zhang, L., 2012. A meta-analysis of mobile commerce adoption and the moderating effect of culture, Computers in Human Behaviour, Vol. 28 (5), Hal. 1902-1911.

47. https://www.cermati.com/artikel/sudah-punya-e-money-ini-jenis-dan-daftar-produk-yangbanyak-digemari, accessed on 5 November 2017.

48. https://pilihkartu.com/informasi-kartu-kredit/jenisjenis-emoney-di-indonesia, accessed on 5 November 2017.

49. http://www.cs.virginia.edu/ cs458/slides/module04-internetV2.pdf, retrieved November 16, 2017.

50. http://isparmo.web.id/2016/11/21/data-statistik-pengguna-internet-indonesia-2016/, retrieved November 16, 2017.

51. http://www.tempo.co/read/kolom/2015/10/02/2310/indonesia-raksasa-teknologi-digitalasia, retrieved November 16, 2017.

52. http://ekonomi.kompas.com/read/2017/09/28/120000326/uang-elektronik-vs-dompetelektronik-mana-yang-lebih-menarik-digunakan, retrieved November 16, 2017.

53. http://www.bi.go.id/id/statistik, retrieved November 16, 2017. 